\title{
NITROGEN ACCUMULATION PROFILES OF SELECTED GRAIN AND VEGETABLE CROPS:
}

\section{A BIBLIOGRAPHY (1940-1992)}

S. J. Meischen, Chemical Research Department

${ }^{*} \mathrm{~K}$. R. Byrd, Technology Introduction

*Currently at Middle Tennessee State University, Murfreesboro, Tennessee

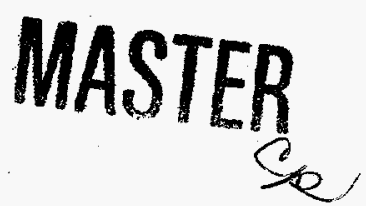




\section{DISCLAIMER}

This report was prepared as an account of work sponsored by an agency of the United States Government. Neither the United States Government nor any agency thereof, nor any of their employees, make any warranty, express or implied, or assumes any legal liability or responsibility for the accuracy, completeness, or usefulness of any information, apparatus, product, or process disclosed, or represents that its use would not infringe privately owned rights. Reference herein to any specific commercial product, process, or service by trade name, trademark, manufacturer, or otherwise does not necessarily constitute or imply its endorsement, recommendation, or favoring by the United States Government or any agency thereof. The views and opinions of authors expressed herein do not necessarily state or reflect those of the United States Government or any agency thereof. 


\section{DISCLAIMER}

Portions of this document may be illegible in electronic image products. Images are produced from the best available original document. 


\section{Contents}

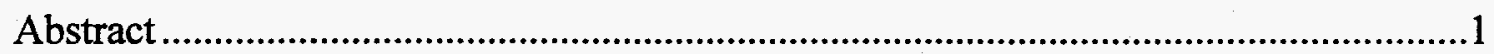

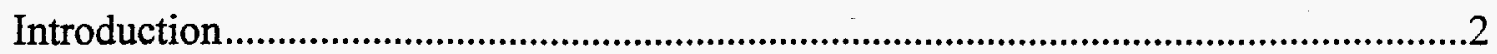

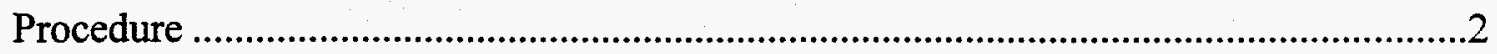

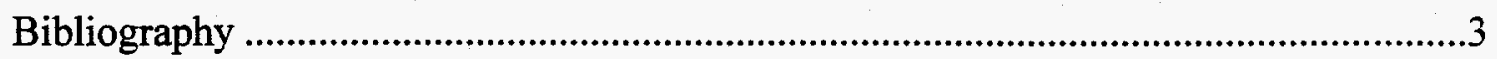

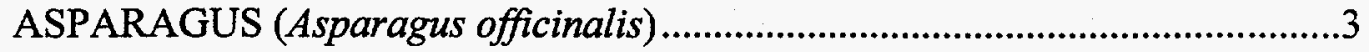

BROCCOLI (Brassica oleracea) ...................................................................

BRUSSELS SPROUTS (Brassica olerscea) .......................................................

CABBAGE (Brassica oleracea var. capitata) .....................................................3

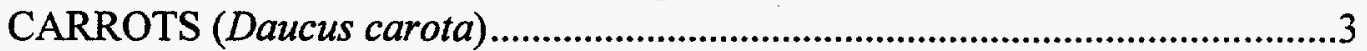

CAULIFLOWER (Brassica oleracea var. botrytis) ..............................................

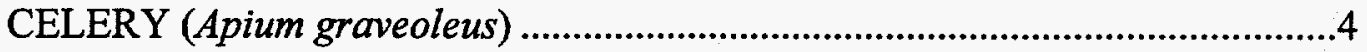

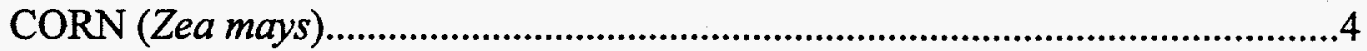

COTTON (Gossypium hirsutum) ...............................................................6

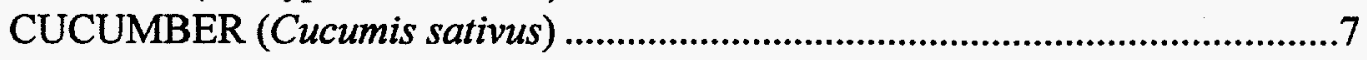

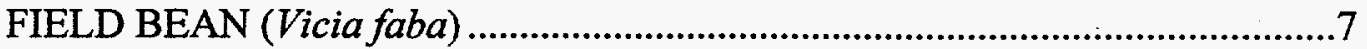

FIELD PEA (Pisum arveuse and Pisum sativum) ..........................................

GARLIC (Allium sativum) ......................................................................8

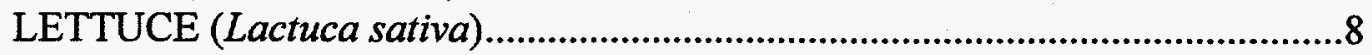

ONIONS (Allium cepa)............................................................................

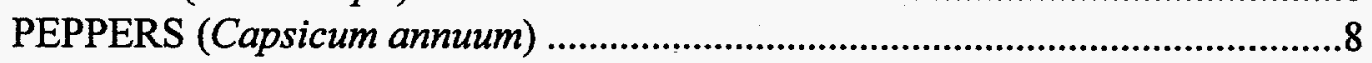

POTATOES (Solanum tuberosum) ............................................................9

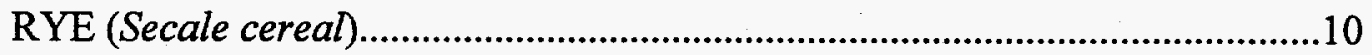

SNAP BEANS (Phaseolus vulgaris) ...........................................................10

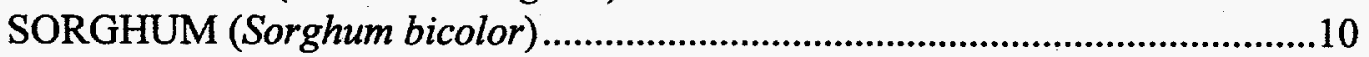

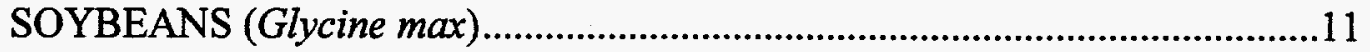

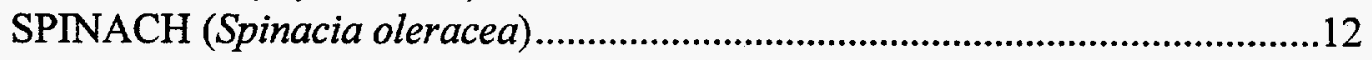

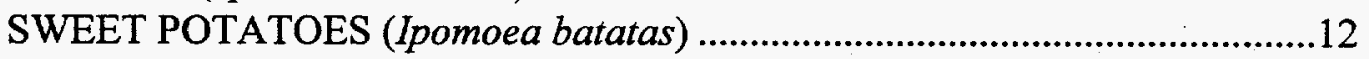

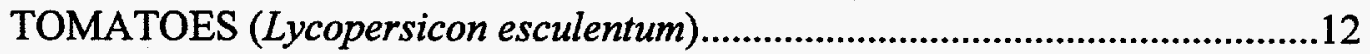

WHEAT (Triticum aestivum) .......................................................................13 


\title{
NITROGEN ACCUMULATION PROFILES OF SELECTED GRAIN AND VEGETABLE CROPS: A BIBLIOGRAPHY (1940-1992)
}

\begin{abstract}
A bibliography of nitrogen accumulation profile data for 25 vegetable and grain crops reported between 1940 and 1992 is presented. The selected crops are asparagus, broccoli, brussels sprouts, cabbage, carrots, cauliflower, celery, corn, cotton, cucumber, field bean, field pea, garlic, lettuce, onions, peppers.
\end{abstract}

Key Words: uptake, asparagus, broccoli, brussels sprouts, cabbage, carrots, cauliflower, celery, corn, cotton, cucumber, field bean, field pea, garlic, lettuce, onions, peppers, potatoes, rye, snap beans, sorghum, soybeans, spinach, sweet potatoes, tomatoes, wheat 


\section{Introduction}

A current program supported by the Tennessee Valley Authority's National Environmental Research Center is to develop controlled availability nitrogen products that supply adequate nitrogen to a crop while minimizing nitrate leaching to ground water. Slow-release nitrogen fertilizers such as sulfur-coated urea and urea formaldehydes are the most common controlled availability products on the market today. However, these controlled availability products were not developed to minimize nitrate leaching and there is little, if any, definitive data to support that assumption. In order to validate the concept that use of controlled availability fertilizers can reduce nitrate leaching with respect to conventional fertilizers, information on the nitrogen demand of various crops and cropping systems and the influencing variables is required. The nitrogen uptake profile of a crop and pattern of $\mathrm{N}$ supply from the soil are important considerations in optimizing the pattern of nitrogen release from controlled availability fertilizers. This bibliography is a compilation of literature references containing data on nitrogen accumulation patterns for selected crops.

\section{Procedure}

The Agricola (1970-1992) and CAB abstracts (1980-1992) databases were sources for the majority of the citations. Search terms used were: "the crop name," "nutrient or nitrogen," and "uptake or accumulation," which results in over 3500 citations. Publication selection was guided by the abstract contents. Each publication was examined for profile data. Any publication reference to other published reports that may contain profile data was examined as well. All citations earlier than 1970 were identified from publication references. The period of the bibliography is $1940-1992$.

The publications cited contain nitrogen uptake information on either the whole plant or the above-ground plant parts. Those publications that reported uptake data for only selected aboveground parts of plants were not included. A majority of the cited publications graphically display nitrogen accumulation profiles and those without a profile contain the data to produce a profile. Appropriate nitrogen accumulation profile data were not found for asparagus, brussels sprouts, and carrots; but to indicate their inclusion in the search they are listed in the bibliography. 


\section{Bibliography}

\section{ASPARAGUS (Asparagus officinalis)}

\section{BROCCOLI (Brassica oleracea)}

1. Doerge, T.A., R.L. Roth, and B.R. Gardner. 1991. Nitrogen fertilizer management in Arizona. College of Agriculture, The University of Arizona.

2. Letey, J., W.M. Jarrell, N. Valoras, and R. Beverly. 1983. Fertilizer application and irrigation management of broccoli production and fertilizer use efficiency. Agron. J. 75:502-507.

3. Magnifico, V., V. Lattanzio, and G. Sarli. 1979. Growth and nutrient removal by broccoli. J. Am. Soc. Hortic. Sci. 104(2):201-203.

\section{BRUSSELS SPROUTS (Brassica olerscea)}

\section{CABBAGE (Brassica oleracea var. capitata)}

4. Doerge, T.A., R.L. Roth, and B.R. Gardner. 1991. Nitrogen fertilizer management in Arizona. College of Agriculture, The University of Arizona.

5. Huett, D.O., and E.B. Dettmann. 1989. Effect of nitrogen on growth, quality and nutrient uptake of cabbages grown in sand culture. Australian J. Exp. Agric. 29:875-81.

6. Welch, N. C., K. B. Tyler, and D. Ririe. 1985. Cabbage yield and nutrient uptake. California Agric., July-August:30-31.

\section{CARROTS (Daucus carota)}

\section{CAULIFLOWER (Brassica oleracea var. botrytis)}

7. Doerge, T.A., R.L. Roth, and B.R. Gardner. 1991. Nitrogen fertilizer management in Arizona. College of Agriculture, The University of Arizona. 


\section{CELERY (Apium graveoleus)}

8. Geraldson, C.M., and K.B. Tyler. 1990. Plant analysis as an aid in fertilizing vegetable crops, p. 549-562. In R.L. Westerman (ed.) Soil testing and plant analysis. Soil Sci. Soc. Am., Madison, WI.

9. Lorenz, O.A., and J.F. Bartz. 1968. Fertilization for high yields and quality of vegetable crops, p. 327-352. In R.C. Dinauer (ed.) Changing patterns in fertilizer use. Proc. Soil Sci. Soc. Am.

10. Stark, J.C., W.M. Jarrell, and J. Letey. 1982. Relationships between growth and nitrogen fertilization of celery. HortScience. 17(5):754-755.

11. Zink, F.W. 1963. Rate of growth and nutrient absorption of celery. Proc. Am. Soc. Hortic. Sci. 82:351-357.

\section{CORN (Zea mays)}

12. Andre, M., D. Massimino, and A. Daguenet. 1978. I. Daily patterns under the life cycle of a maize crop. II. Mineral nutrition root respiration and root excretion. Physiol. Plant 44:197204.

13. Bigeriego, M., R.D. Hauck, and R.A. Olson. 1979. Uptake, translocation and utilization of $15 \mathrm{~N}$-depleted fertilizer in irrigated corn. Soil Sci. Soc. Am. J. 43:528-533.

14. Broadbent, F.E. 1984. Plant use of soil nitrogen, p. 171-182. In R. L. Hauck (ed.) Nitrogen in crop production. Am. Soc. Agron., Madison, WI.

15. Chandler, W.V. 1960. Nutrient uptake by corn in North Carolina. N.C. Agric. Exp. Stn. Tech. Bul. 143.

16. Doerge, T.A., R.L. Roth, and B.R. Gardner. 1991. Nitrogen fertilizer management in Arizona. College of Agriculture, The University of Arizona.

17. Flannery, R.L. 1986. Plant food uptake in a maximum yield corn study. Better Crops/Fall, 4-5.

18. Hanway, J.J. 1962. Corn growth and composition in relation to soil fertility: II. Uptake of $\mathrm{N}, \mathrm{P}$, and $\mathrm{K}$ and their distribution in different plant parts during the growing season. Agron. J. 54:217-222.

19. Hanway, J.J. 1962. Plant analysis guide for corn needs. Better Crops with Plant Food. $46(3): 50-55$. 
20. Hanway, J.J. 1971. How a corn plant develops. Iowa State Univ. Coop. Ext. Serv. Spec. Rep. 48.

21. Hay, R.E., E.B. Earley, and E.E. DeTurk. 1953. Concentration and translocation of nitrogen compounds in the corn plant (Zea mays) during grain development. Plant Physiol. 28:606621.

22. Jordan, H.V., K.D. Laird, and D.D. Ferguson. 1950. Growth rates and nutrient uptake by corn in a fertilizer-spacing experiment. Agron. J. 42:261-268.

23. Karlen, D.L., E.J. Sadler, and C.R. Camp. 1987. Dry matter, nitrogen, phosphorus, and potassium accumulation rates by corn on Norfolk loamy sand. Agron. J. 79:649-656.

24. Karlen, D.L., R.L. Flannery, and E.J. Sadler. 1987. Nutrient and dry matter accumulation rates for high yielding maize. J. Plant Nutri. 10:1409-1417.

25. Karlen, D.L., R.L. Flannery, and E.J. Sadler. 1988. Aerial accumulation and partitioning of nutrients by corn. Agron. J. 80:232-242.

26. Larson, W.E., and J.J. Hanway. 1977. Corn production. In Sprague (ed.) corn and corn improvement. Agronomy 18:625-669.

27. Mills, L.A., and W. S. McElhannon. 1982. Nitrogen uptake by sweet corn. HortScience. 17(5):743-744.

28. Olness, A. 1984. Tillage effects on nitrogen uptake by maize from fine textured soils in the northwestern Corn Belt, USA. Plant and Soil 76:67-73.

29. Olness, A., G.R. Beniot, K.Van Sickle, and J. Rinke. 1990. Effect of planting date on time and rate of nitrogen accumulation by maize (Zea mays L.). J. Agron. \& Crop Sci. 164:4253.

30. Olness, A., and G.R. Benoit. 1992. A closer look at corn nutrient demand. Better Crops: Spring, p. 18-20.

31. Osaki, M., K. Morikawa, T. Shinano, M. Urayama, and T. Tadano. 1991. Productivity of high-yielding crops. II. Comparison of $\mathrm{N}, \mathrm{P}, \mathrm{K}, \mathrm{Ca}$, and $\mathrm{Mg}$ accumulation and distribution among high-yielding crops. Soil Sci. Plant Nutr. 37:445-454.

32. Rhoads, F.M., and R.L. Stanley, Jr. 1981. Fertilizer scheduling, yield, and nutrient uptake of irrigated corn. Agron. J. 73:971-974.

33. Ritchie, S.W., and J. J. Hanway. 1986. How a corn plant develops. Iowa State Univ. Coop. Ext. Serv. Spec. Rep. 48. 
34. Sayre, J.D. 1948. Mineral accumulation in com plant. Plant Physiology. 23:267-281

35. Sayre, J.D. 1955. Mineral nutrition of corn. In George F. Sprague (ed.) Corn and corn improvement. Agron. 5:293-314. Academic Press, New York.

36. Terman, G.L., J.C. Noggle, and C.M. Hunt. 1977. Growth rate-nutrient concentration relationships during early growth of corn as affected by applied N, P, K. Soil Sci. Soc. Am. J. 4l:363-368.

37. Timmons, D.R., T.M. Crosbie, R.M. Cruse, D.C. Erbach, and K.N. Potter. 1986. Effect of tillage and corn hybrids on N, P, and K uptake at different growth stages. Maydica. 31:279293.

\section{COTTON (Gossypium hirsutum)}

38. Basset, D.M., W.D. Anderson, and C.H.E. Werkhoven. 1970. Dry matter production and nutrient uptake in irrigated cotton (Gossypium hirsutum). Agron. J. 62:299-303.

39. Bhatt, J.G., and E. Appukuttan. 1971. Nutrient uptake in cotton in relation to plant architecture. Plant and Soil. 35:381-388.

40. Doerge, T.A., R.L. Roth, and B.R. Gardner. 1991. Nitrogen fertilizer management in Arizona. College of Agriculture, The University of Arizona.

41. Eaton, F.M., D.R. Ergel. 1957. Mineral nutrition of cotton plant. Plant Physiol. 32:169-174.

42. Halevy, J. 1976. Growth rate and nutrient uptake of two cotton cultivars grown under irrigation. Agron. J. 68:701-705.

43. Halevy, J., A. Marani, and T. Markovitz. 1987. Growth and NPK uptake of high-yielding cotton grown at different nitrogen levels in a permanent-plot experiment. Plant and Soil. 103:39-44.

44. Mullins, G.L., and C.H. Burmester. 1990. Dry matter, nitrogen, phosphorus, and potassium accumulation by four cotton varieties. Agron. J. 82:729-736.

45. Olson, L.C., R.P. Bledsoe. 1942. The chemical composition of the cotton plant and the uptake of nutrients at different stages of growth. Geo. Agri. Exp. Stn. Bull. 222.

46. Sabbe, W.E., and L.J. Zelinski. 1990. Plant analysis as an aid in fertilizing cotton, p. 469493. In R.L. Westerman (ed.) Soil testing and plant analysis, 3rd ed. Soil Sci. Soc. Am., Madison, WI. 


\section{CUCUMBER (Cucumis sativus)}

47. Ward, G.M. 1967. Growth and nutrient absorption in greenhouse tomato and cucumber. Amer. Soc. Hortic. Sci. 90:335-341.

\section{FIELD BEAN (Vicia faba)}

48. Cooper, D.R., D.G. Hill-Cottingham, and C.P. Lloyd-Jones. 1976. Absorption and redistribution of nitrogen during growth and development of field bean, vicia faba. Physiol. Plant. 38:313-318.

49. Dantuma, G., and J.A.K. Hulze. 1978. Production and distribution of dry matter, and uptake, distribution and redistribution of nitrogen in Vicia faba major and minor. Some current research on vicia faba in western Europe. Office for Official Publications of the European Communities, Luxembourg. p. 396-406.

50. Herdina, H., and J.H. Silsbury. 1990. Growth, nitrogen accumulation and partitioning, and $\mathrm{N}_{2}$ fixation in faba bean (Vicia faba cv. Fiord) and pea (Pisum sativum cv. Early Dun). Field Crops Res. 24:173-188.

51. Sprent, J.I., and A.M. Bradford. 1977. Nitrogen fixation in field beans (Vicia faba) as affected by population density, shading and its relationship with soil moisture. J. Agric. Sci., Camb.

\section{FIELD PEA (Pisum arveuse and Pisum sativum)}

52. Herdina, H., and J.H. Silsbury. 1990. Growth, nitrogen accumulation and partitioning, and N2 fixation in faba bean (vicia faba cv. fiord) and pea (pisum sativum cv. early dun). Field Crops Res. 24:173-188.

53. Jensen, E.S. 1986. Seasonal patterns of growth and nitrogen fixation in field-grown pea. Plant and Soil. 101:29-37.

54. Kucey, R.M.N. 1989. Contribution of $\mathrm{N}_{2}$ fixation to field bean and pea $\mathrm{N}$ uptake over the growing season under field conditions in Southern Alberta. Cam. Soil Sci. 69:695-699.

55. Lorenz, O.A., and J.F. Bartz. 1968. Fertilization for high yields and quality of vegetable crops, p. 327-352. In R.C. Dinauer (ed.) changing patterns in fertilizer use. Proc. Soil Sci. Soc. Am.

56. Pate, J.S., and A.M. Flinn. 1973. Carbon and nitrogen transfer from vegetative organs to ripening seeds of field pea (pisum arvense L.). J. Exp. Botany 24(83):1090-1099. 


\section{GARLIC (Allium sativum)}

57. Zink, F.W. 1963. Rate of growth and nutrient absorption of late garlic. Amr. Soc. Hortic. Sci. 83:579-589.

\section{LETTUCE (Lactuca sativa)}

58. Doerge, T.A., R.L. Roth, and B.R. Gardner. 1991. Nitrogen fertilizer management in Arizona. College of Agriculture, The University of Arizona.

59. Huett, D.O., and E.B. Dettmann. 1992. Nutrient uptake and partitioning by zucchini squash, head lettuce and potato in response to nitrogen. Aust. J. Agric. Res. 43:1653-65.

60. Lorenz, O.A., and J.F. Bartz. 1968. Fertilization for high yields and quality of vegetable crops, p. 327-352. In R.C. Dinauer (ed.) Changing patterns in fertilizer use. Proc. Soil Sci. Soc. Am.

61. Zink, F.W., and M. Yamaguchi. 1962. Studies on the growth rate and nutrient absorption of head lettuce. Hilgardia. 32(11):471-500.

\section{ONIONS (Allium cepa)}

62. Zink, F.W. 1961. Growth and nutrient absorption of green bunching onions. Am. Soc. Hortic. Sci. 80:430-435.

63. Zink, F.W. 1966. Studies on the growth rate and nutrient absorption of onion. Hilgardia. 37(8):203-218

\section{PEPPERS (Capsicum annuum)}

64. Locascio, S.J., J.G.A. Fiskell, D.A. Graetz, and R.D. Hauck. 1985. Nitrogen accumulation by pepper as influenced by mulch and time of fertilizer application. J. Am. Soc. Hortic. Sci. $110(3): 325-328$.

65. Marti, H. R., and H. A. Mills. 1991. Nutrient uptake and yield of sweet pepper as affected by stage of development and N form. J. Plant Nutri. 14(11):1165-1175.

66. Miller, C.H., R.E. McCollum, and S. Claimon. 1979. Relationships between growth of bell peppers (capsicum annuum L.) and nutrient accumulation during ontogeny in field environments. J. Am. Soc. Hortic. Sci. 104(6):852-857. 
67. Tapia, M.L., and R. Dabed. 1984. Nutrient update by sweet pepper grown in quartz. ISOSC Proc. 683-696.

\section{POTATOES (Solanum tuberosum)}

68. Asfary, A.F., A. Wild, and P.M. Harris. 1983. Growth, mineral nutrition and water use by potato crops. J. Agric. Sci., Camb. 100:87-101.

69. Cameron, D.R., R. DeJong, and C. Chang. 1978. Nitrogen inputs and losses in tobacco, bean, and potato fields in a sandy loam watershed. J. Environ. Qual. 7(4):545-550.

70. Doerge, T.A., R.L. Roth, and B.R. Gardner. 1991. Nitrogen fertilizer management in Arizona. College of Agriculture, The University of Arizona.

71. Huett, D.O., and E.B. Dettmann. 1992. Nutrient uptake and partitioning by zucchini squash, head lettuce and potato in response to nitrogen. Aust. J. Agric. Res. 43:1653-65.

72. Jackson, R. D., and J. L. Haddock. 1959. Growth and nutrient uptake of Russet Burbank potatoes. J. Am. Potato. 36:22-28.

73. Kleinkopf, G.E., D.T. Westermann, and R.B. Dwelle. 1981. Dry matter production and nitrogen utilization by six potato cultivars. Agron. J. 73:799-802.

74. Lauer, D.A. 1985. Nitrogen uptake patterns of potatoes with high-frequency sprinklerapplied N fertilizer. Agron. J. 77:193-197.

75. Lorenz, O.A. 1947. Studies on potato nutrition. II. Nutrient uptake at various stages of growth by Kern county potatoes. Proc. Am. Soc. Horti. Sci. 44:389-394.

76. Lorenz, O.A., and J.F. Bartz. 1968. Fertilization for high yields and quality of vegetable crops. p. 327-352. In R.C. Dinauer (ed.) Changing patterns in fertilizer use. Proc.Soil Sci. Soc. Am. 327-352.

77. Millard, P., and B. Marshall. 1986. Growth, nitrogen uptake and partitioning within the potato (solanum tuberosum L.) crop, in relation to nitrogen application. J. Agric. Sci., Camb. 107:421-429

78. Millard, P., D. Robinson, and L. A. Mackie-Dawson. 1989. Nitrogen partitioning within the potato (solanum tubersom L.) plant in relation to nitrogen supply. Annals of Botany 63:289-296.

79. Millard, P., and D. Robinson. 1990. Effect of the timing and rate of nitrogen fertilization on the growth and recovery of fertilizer nitrogen within the potato (Solanum tuberosum L.) crop. Fert. Res. 21:133-140. 
80. Osaki, M., K. Morikawa, T. Shinano, M. Urayama, and T. Tadano. 1991. Productivity of high-yielding crops. II. Comparison of $\mathrm{N}, \mathrm{P}, \mathrm{K}, \mathrm{Ca}$, and $\mathrm{Mg}$ accumulation and distribution among high-yielding crops. Soil Sci. Plant Nutri. 37(3):445-454.

81. Soltanpour, P. N. 1969. Accumulation of dry matter and N, P, K, by Russet Burbank, Oromonte and Red McClure potatoes. J. Am. Potato 46:111-119.

\section{RYE (Secale cereal)}

82. Joarder, O.I., M.A. Azam, M.M. Uddin, S.K. Bhadra, M.A. Khaleque, and A.M. Eunus. 1984. Growth and nitrogen, phosphorus and potassium uptake by triticale and rye. Acta Agron Acad. Sci. Hung. 33:192-201.

83. Rumburg, C.B. and F. A. Sneva. 1970. Accumulation and loss of nitrogen during growth and maturation of cereal rye (secale cereale). Agron. J. 62(3):311-313.

\section{SNAP BEANS (Phaseolus vulgaris)}

84. Busada, C.J., J.B. Jones, Jr., and H.A. Mills. 1982. Major element uptake by snap bean grown in nutrient culture with varying nitrogen solution treatments. J. Plant Nutri. 5(1):63-71.

85. Kucey, R.M.N. 1989. Contribution of $\mathrm{N}_{2}$ fixation to field bean and pea $\mathrm{N}$ uptake over the growing season under field conditions in Southern Alberta. Can. Soil Sci. 69:695-699.

86. Peck, N.H., and G.E. MacDonald. 1984. Snap bean plant responses to nitrogen fertilization. Agron. J. 76:247-253.

87. Porter, Michael A., and Bernard Grodzinski. 1989. Growth of bean in high $\mathrm{C}_{2}$ : effects on shoot mineral composition. J. Plant Nutri. 12(2):129-144.

88. Smith, D.L., M. Dijak, and D.J. Hume. 1988. Effects of irrigation and fertilizer N on N accumulation and partitioning in white bean and soybean. Can. J. Plant Sci. 68:31-39.

89. Westermann, D.T., L.K. Porter, and W.A. O'Deen. 1985. Nitrogen partitioning and mobilization patterns in bean plants. Crop Sci. 25:225-229.

\section{SORGHUM (Sorghum bicolor)}

90. Doerge, T.A., R.L. Roth, and B.R. Gardner. 1991. Nitrogen fertilizer management in Arizona. College of Agriculture, The University of Arizona. 
91. Lane, H.C., and H.J. Walker, 1961. Mineral accumulation and distribution in grain sorghum. Texas Agri. Exp. Stn., M.P. 533:3-9.

92. Roy, R.N., and B.C. Wright. 1974. Sorghum growth and nutrient uptake in relation to soil fertility, II. N, P, and K uptake pattern by various plant parts. Agron. J. 66:5-10.

93. Sah, R.N., S. Geng, Y.P. Puri, and V.E. Rubatzky. 1987. Evaluation of four crops for nitrogen utilization and carbohydrate yield. Fert. Res. 13:55-70.

94. Smith, F.W., and R.J. Myers. 1978. Patterns of uptake and distribution of phosphorus and nitrogen in grain sorghum during its development. Plant Nutri. p. 491-498.

95. Vanderlip, R.L. How a sorghum plant develops. Kans. State Univ. Coop. Ext. Ser. Contribution No. 1203.

\section{SOYBEANS (Glycine max)}

96. Burton, J.W., R.F. Wilson, and C.A. Brim. 1979. Dry matter and nitrogen accumulation in male-sterile and male-fertile soybeans. Agron. J. 71:548-552.

97. Flannery, R.L. 1986. Plant food uptake in a maximum yield soybean study. Better Crops:Fall. 97.

98. Hammond, L.C., C.A. Black, and A.G. Norman. 1951. Nutrient uptake by soybeans on two Iowa soils. Iowa Agr. Exp. Stn. Research Bull. No. 384.

99. Hanway, J.J., and C.R. Weber. 1971. Accumulation of N, P, and K by soybean (Glycine $\max ($ L.) Merrill) plants. Agron. J. 63:406-408.

100. Hanway, J.J., and H.E. Thompson. 1971. How a soybean plant develops. Iowa State Univ. of Science and Technology Coop. Ext. Serv. Spec Rep. 53.

101. Harper, J.E. 1971. Seasonal nutrient uptake and accumulation patterns in soybeans. Crop Sci. 11:347-350.

102. Henderson, J.B., and E.J. Kamprath. 1970 . Nutrient and dry matter accumulation by soybeans. North Carolina Agr. Exp. Stn. Tech. Bul. No. 91.

103. Lathwell, D.J., and C.E. Evans. 1951. Nitrogen uptake from solution by soybeans at successive stages of growth. Agron. J. 43:264-270. 
104. Mason, W.K., H.M. Taylor, A.T.P. Bennie, H.R. Rowse, D.C. Reicosky, Y. Jung, A.A. Righes, R.L.Yang, T.C. Kaspar, and J.A. Stone. 1979. Soybean row spacing and soil water supply: Their effect on growth, development, water relations, and mineral uptake. U.S. Dept. of Agriculture. 1-58.

105. Nelson, A.N., and R.W. Weaver. 1980. Seasonal nitrogen accumulation and fixation by soybeans grown at different densities. Agron. J. 72:613-616.

106. Osaki, M., K. Morikawa, T. Shinano, M. Urayama, and T. Tadano. 1991. Productivity of high-yielding crops. II. Comparison of $\mathrm{N}, \mathrm{P}, \mathrm{K}, \mathrm{Ca}$, and $\mathrm{Mg}$ accumulation and distribution among high-yielding crops. Soil Sci. Plant Nutri. 37(3):445-454.

107. Smith, D.L., M. Dijak, and D.J. Hume. 1988. Effects of irrigation and fertilizer $\mathrm{N}$ on $\mathrm{N}$ accumulation and partitioning in white bean and soybean. Can. J. Plant Sci. 68:31-39.

108. Spaeth, S.C., and T.R. Sinclair. 1983. Variation in nitrogen accumulation and distribution among soybean cultivars. Field Crops Res. 7:1-12.

\section{SPINACH (Spinacia oleracea)}

109. Zink, F.W. 1965. Growth and nutrient absorption in spring spinach. Am. Soc. Hortic. Sci. 87:380-386.

\section{SWEET POTATOES (Ipomoea batatas)}

110. Leonard, O.A., W.S. Anderson, and M. Geiger. 1948. Effect of nutrient level on the growth and chemical composition of sweet potatoes in sand cultures. Plant Physiol. 23:223-237.

111. Scott, L.E., and J.C. Bouwkamp. 1974. Seasonal mineral accumulation by the sweet potato. Hortic. Sci. 9(3):233-235.

112. Scott, L.E., and W.L. Ogle. 1952. The mineral uptake by the sweet potato. Better Crops with Plant Food 36(8):12-16, 50.

\section{TOMATOES (Lycopersicon esculentum)}

113. Broadbent, F.E. 1984. Plant use of soil nitrogen, p. 171-182. In R.L.Hauck (ed.) Nitrogen in crop production. Am. Soc. Agron., Madison, WI.

114. Halbrooks, Mary C. and G.E. Wilcox. 1980. Tomato plant development and elemental accumulation. J. Am. Soc. Hortic. Sci. 105(6):826-828. 
115. Huett, D.O., and E. B. Dettmann. 1988. Effect of nitrogen on growth, fruit quality and nutrient uptake of tomatoes grown in sand culture. Austialian J. of Exp. Agri. 28:391-399

116. Tanaka, Akira, K. Fujita, and K. Kikuchi. 1974. Nutrio-physiological studies on the tomato plant. Soil Sci. Plant Nutri. 20(1):57-68.

117. Ward, G.M. 1967. Growth and nutrient absorption in greenhouse tomato and cucumber. Am. Soc. Horti. Sci. 90:335-341.

\section{WHEAT (Triticum aestivum)}

118. Baethgen, W.E., and M.M. Alley. 1989. Optimizing soil and fertilizer nitrogen use by intensively managed winter wheat. I. Crop nitrogen uptake. Agron. J. 81:116-120.

119. Berczi, A., Z. Olah, and L. Erdei. 1983. Nutrition of winter wheat during the life cycle. I. Yield and accumulation of dry matter and minerals. Physiol. Plant. 58:124-130.

120. Boatwright, G.O., and H.J. Haas. 1961. Development and composition of spring wheat as influenced by nitrogen and phosphorus fertilization. Agron. J. 53:33-36.

121. Chand, M., and G. Dev. 1986. Comparative performance of wheat, barley and oats for dry matter production and $\mathrm{N}$ uptake as affected by nitrogen fertilization. Intern. J. Trop. Agric. $4(3): 251-257$.

122. Clarke, J.M., C.A. Campbell, H.W. Cutforth, R.M. DePauw, and G.E. Winkleman. 1990. Nitrogen and phosphorus uptake, translocation, and utilization efficiency of wheat in relation to environment and cultivar yield and protein levels. Can. J. Plant Sci. 70:965-977.

123. Doerge, T.A., R.L. Roth, and B.R. Gardner. 1991. Nitrogen fertilizer management in Arizona. College of Agriculture, The University of Arizona.

124. Gasser, J.K.R., and M.A.P. Thorburn. 1972. The growth, composition and nutrient uptake of spring wheat. Effects of fertilizer-N, irrigation and $\mathrm{CCC}$ on dry matter and $\mathrm{N}, \mathrm{P}, \mathrm{K}, \mathrm{Ca}$, $\mathrm{Mg}$ and Na. J. Agric. Sci., Camb. 78:393-404.

125. Gregory, P.J., D.V. Crawford, and M.McGowan. 1979. Nutrient relations of winter wheat. I. Accumulation and distribution of $\mathrm{Na}, \mathrm{K}, \mathrm{Ca}, \mathrm{Mg}, \mathrm{P}, \mathrm{S}$ and N. J. Agric. Sci., Camb. 93:485-494.

126. Halloran, G.M., and J.W. Lee. 1979. Plant nitrogen distribution in wheat cultivars. Aust. J. Agric. Res. 30:779-89.

127. Johnston, A.M., and D.B. Fowler. 1991. No-till winter wheat dry matter and tissue nitrogen response to nitrogen fertilizer form and placement. Agron. J. 83:1035-1043. 
128. Karlen, D.L., and E.J. Sadler. 1990. Nutrient accumulation rates for wheat in the southern coastal plain. Commun. In Soil Sci. Plant Anal. 21(13-16):1329-1352.

129. Lal, P., G.G. Reddy, and M.S. Modi. 1978. Accumulation and redistribution pattern of dry matter and $\mathrm{N}$ in triticale and wheat varieties under water stress condition. Agron. J. 70:623626.

130. Lal, P., and K.C. Sharma. 1973. Accumulation and redistribution pattern of nitrogen and dry matter in dwarf wheat as influenced by soil moisture and nitrogen fertilization. Indian J. Agric. Sci. 43(5):486-492.

131. Lasztity, B., G. Biczok, and M. Ruda. 1984. Evaluation of dry matter and nutrient accumulation in winter wheat. Cereal Res. Commun. 12(3-4):193-199.

132. McNeal, F.H., M.A. Berg, and C.A. Watson. 1966. Nitrogen and dry matter in five spring wheat varieties at successive stages of development. Agron. J. 58:605-608.

133. McNeal, F.H., G.O. Boatwright, M.A. Berg, and C.A. Watson. 1968. Nitrogen in plant parts of seven spring wheat varieties at successive stages of development. Crop Sci. 8:535537.

134. Miller, E. C. 1939. A physiological study of the winter wheat plant at different stages of its development. Kansas Agri. Exp. Stn. Tech. Bull. 47.

135. Osaki, M., K. Morikawa, T. Shinano, M. Urayama, and T. Tadano. 1991. Productivity of high-yielding crops. II. Comparison of N, P, K, Ca, and $\mathrm{Mg}$ accumulation and distribution among high-yielding crops. Soil Sci. Plant Nutri. 37(3):445-454.

136. Page, M.B., J.L. Smalley, and O. Talibudeen. 1977. The growth and nutrient uptake of winter wheat. Plant and Soil. 49:149-160.

137. Power, J.F., D.L. Grunes, and G.A. Reichman. 1961. The influence of phosphorus fertilization and moisture on growth and nutrient absorption by spring wheat: I. Plant growth, N uptake, and moisture use. Soil Sci. Soc. Am. Proc. 25:207-210.

138. Waldren, R.P., and A.D. Flowerday. 1979. Growth stages and distribution of dry matter, N, $\mathrm{P}$, and $\mathrm{K}$ in winter wheat. Agron. J. 71:391-397. 